\title{
PODER MILITAR E IDENTIDADE DE GRUPO NA SEGUNDA GUERRA MUNDIAL: A EXPERIÊNCIA HISTÓRICA DA PSIQUIATRIA MILITAR BRASILEIRA
}

\author{
Dennison de Oliveira*
}

\begin{abstract}
RESUMO
Este artigo se propõe a discutir, com relação à experiência militar da Força Expedicionária Brasileira (FEB) na Campanha da Itália (1944/ 45) na Segunda Guerra Mundial, dois aspectos que a literatura disponível considera centrais para o entendimento da organização da violência a partir das instituições militares: as formas pelas quais se dá a construção de uma identidade coletiva entre os seus membros e o papel que dentro desse processo é desempenhado pelos sentimentos experimentados pelos indivíduos. Este artigo pretende interpretar as evidências legadas sobre esses tópicos a partir de fontes fontes legadas pela História Militar e pela Psiquiatria Militar brasileiras numa perspectiva interdisciplinar.

Palavras-chave: História Contemporânea, Segunda Guerra Mundial, Força Expedicionária Brasileira, violência institucional, sentimentos, identidades coletivas.
\end{abstract}

\begin{abstract}
This article intends to discuss, with relationship to the military experience of the Brazilian Expeditionary Force (FEB) in the Campaign of Italy (1944/45) in Second World War, two aspects that the available literature considers central for the understanding of the organization of the violence starting from the military institutions: the forms for the which works the construction of a collective identity among of its members and the paper that inside of this process it is carried out by the feelings tried by
\end{abstract}

\footnotetext{
* Professor Adjunto do Departamento de História da Universidade Federal do Paraná; Doutor em Ciências Políticas pela Unicamp (1995).
} 
the individuals. This text intends to interpret the evidences delegated on these topics starting from sources available by the Military History and for the Psychiatry Military Brazilians in a interdisciplinar perspective.

Key-words: Contemporary History, Second World War, Expeditionary Brazilian Force, institutional violence, feelings, collective identities.

\section{Introdução: lutar, fingir lutar, fugir-um problema clássico na Psicologia e História Militares}

As táticas eram acima de tudo táticas de pequenas unidades. Uma ofensiva poderia começar em nível de exército, mas gradualmente ela se dissolvia nos cimos das montanhas em ações isoladas por parte das companhias, pelotões e até grupos de combate, separados uns dos outros por ravinas e montanhas, e tendo como foco uma casamata alemã ou posição de metralhadora em particular. Ajuda vinda da retaguarda nesse tipo de guerra somente poderia consistir de encorajamento e envio de suprimentos por mulas e carregadores, com auxílio eventual de alguma aeronave que aparecesse subitamente ou alguma concentração de artilharia dirigida pelos observadores avançados. A posição das nossas espalhadas unidades raramente podia ser dada de forma precisa; as tropas de vanguarda tinham sempre de estar preparadas para se defender de ataques vindos de todos os lados. Quando a lama e a chuva eram adicionadas ao padrão usual da guerra de montanha, cada avanço se tornava incrivelmente difícil. (STARR, 1947, p. 447)

- Pois bem: vocês irão somente até aí. Não avancem mais. E tratem de se abrigar e façam alguns disparos... é o que basta. O alemão estará perto e vai responder com seus tiros e rajadas de metralhadoras, granadas de morteiros, very-light... o diabo! A noite pega fogo e vocês não terão condições de prosseguir. Quem vai saber o que se passou lá naqueles barrocões escuros? $\mathrm{Na}$ volta você inventa a sua história, conta bravatas que irão impressionar ao comando: chocou-se com uma patrulha inimiga, trocaram tiros e eles foram derrotados, mas como a 
frente foi alertada, não houve outra solução que retornar. Não há como duvidar: os tiros foram ouvidos as bombas explodiram e os very-light iluminaram a noite. E você, com a sua patrulha, estava lá combatendo...

- Agradeço, Ari, a sua atenção e as sua solidariedade para comigo. Mas você sabe que eu irei!...

- Sei que você vai. E gostaria de evitar esse sacrifício inútil que me revolta. Os sacrifícios só podem ser exigidos por motivos muito fortes, nos momentos próprios, quando atacamos ou quando somos atacados. (SOARES, 1985, p. 269)

O tema da agressividade humana tem ocupado um lugar de destaque nas interpretações das origens e motivações da guerra. A agressividade recorrentemente verificável dos seres humanos ocupou, durante muito tempo, lugar de importância nas especulações sobre as causas da persistente tendência das sociedades humanas a apelarem para a guerra como via possível para a resolução de toda sorte de problemas. O debate que se abriu desde então acabou sendo polarizado entre duas tendências importantes.

Uma primeira linha de interpretação que vale a pena ser citada é aquela que diz respeito às determinações de ordem natural da agressão. Nela, os comportamentos agressivos são entendidos como parte dos instintos de preservação tanto de indivíduos quanto de grupos, colocados em situações limite no processo de busca da preservação de suas vidas e/ou preservação do grupo a que pertencem. Fortemente influenciados pela Etologia (LORENZ, 1966), esses estudiosos argumentavam que haveria uma tendência inerente aos seres humanos para agirem de forma agressiva para com seus semelhantes entendida como resultado de uma herança ancestral de seus antepassados antropóides. Essa linha de interpretação foi muito contestada pela antropologia e pela psicologia social, em particular por autores que sublinhavam a influência do darwinismo social na "naturalização" da agressão militar e da conquista imperialista. Como exemplo dessa polêmica, cito os trabalhos de Durbin e Bowlby (1938), Levi (1960) e Pilisuk e Hayden (1965).

Para os primeiros, as causas da guerra devem ser explicadas a partir de uma agressividade comum a todos, que tenta, através da luta, buscar a autopreservação. Nesse sentido, eles rejeitaram a idéia de que a guerra pudesse ser explicada de forma objetiva pelos seus participantes. Segundo esses pensadores, as razões assumidas conscientemente - explicitadas mes- 
mo - pelos agentes da agressão devem ser entendidas como mero resultado de racionalizações para essa mesma agressão. Eles negam que as razões assumidas para a agressão por indivíduos ou grupos possam ser entendidas como necessariamente fundamentadas. Para Durbin e Bowlby essa agressão é entendida como resultado das lutas pelo atendimento de algumas necessidades tidas como básicas e não passíveis de repressão ou sublimação. A satisfação do desejo por comida, espaço e até mesmo aceitação pelo grupo são os casos mencionados por eles.

Fortemente baseados em analogias com comportamentos observáveis no reino animal e em crianças dos primeiros anos de vida, os autores defendem que a agressão tende a ter ocorrência universal entre todos os mamíferos superiores, sem distinção, sempre que a busca pelo atendimento de suas necessidades entre em conflito com os outros indivíduos que pertencem a uma mesma espécie. Isso não impede, ainda segundo eles, que em outras circunstâncias sejam verificados comportamentos cooperativos entre indivíduos da mesma espécie.

No lado oposto, para um autor como Levi (1960), a guerra é motivada principalmente pela ação das elites políticas encarregadas do processo de tomada de decisão que leva ao conflito, entendido como oportunidade de maximizar as vantagens advindas de uma possível vitória. Isso é particularmente verdadeiro no que se refere aos despojos que podem ser obtidos pela guerra de conquista. Levando em conta que é possível demonstrar que existe um nexo entre as motivações declaradas dos atores, bem como encontrar evidência empírica de que os retornos obtidos corresponderam pelo menos em parte às expectativas, podemos defender a hipótese de que existe motivação racional para a guerra. A partir daí, há a pretensão, inclusive, de invalidar as explicações para a guerra baseadas em impulsos relacionados aos instintos. É a famosa tese das origens da guerra como produto das Razões de Estado.

Finalmente, para Plilisuk e Hayden, a principal força motivadora da guerra são os interesses das elites dirigentes do complexo industrialmilitar, tanto públicas quanto privadas, na medida em que a guerra propriamente dita ou a sua permanente ameaça de eclosão (Guerra Fria) justificam amplamente a manutenção e intensificação da corrida armamentista, tornada base da sustentação de seu modo de vida. Aqui, uma vez mais são racionalizações das formas pelas quais se pode lograr o atendimento de seus próprios interesses e não a agressividade "natural", "herdada" ou "inata" 
aos seres humanos que explicam o porquê da ocorrência sucessiva de guerras e conflitos entre os seres humanos e seus semelhantes. A literatura dedicada à busca das origens da guerra é vasta e diversificada, de forma que deixarei apenas indicada aqui a principal polêmica subjacente a essa produção, isto é, a ênfase em determinantes biológicos $o u$ socioculturais da adesão dos seres humanos à agressão contra seus semelhantes.

O objetivo deste artigo é fazer referência a uma questão central relacionada a um outro nível de abstração: as condições pelas quais indivíduos e pequenos grupos decidem perpetrar e/ou se submeter ao padecimento das ações de violência que se realizam no âmbito do campo de batalha.

Uma vez que a guerra tenha sido desencadeada, caberá aos militares travarem os combates e sofrerem as consequiências. Ou decidirem não travar combate algum (por pura e simples inação) ou fazê-lo de forma a privilegiar sua própria segurança (dissimulação de ações reais ao invés de um engajamento verdadeiro, como sugerido na segunda transcrição acima) e até mesmo declarar de forma unilateral a cessação das hostilidades de forma permanente (rendição espontânea, ao invés de captura em combate) ou temporária (tréguas não autorizadas de caráter mais ou menos permanente, geralmente rompidas por ação de outros escalões de combate que ignoram os acordos).

A reflexão sobre esse tópico pretende atender, por um lado, ao interesse de fazer avançar nosso conhecimento sobre a realidade histórica da participação do Brasil na Segunda Guerra Mundial. Estamos assumindo aqui que o desfecho dos episódios relacionados àquela conjuntura dependeu das decisões tomadas tanto pelos indivíduos situados em posições de comando no mais alto nível hierárquico quanto daqueles que efetivamente travaram os combates. Em que pese a importância do debate entre a história militar, que se realiza exclusivamente no âmbito do Estado Maior, e uma nova história militar "vista de baixo" e realizada no mundo anglo-saxão, parece haver pouca dúvida sobre a importância de examinar a história das pequenas unidades da Força Expedicionária Brasileira em combate. Por exemplo, segundo o coronel Floriano de Lima Brayner, comandante do Estado Maior da FEB e ele próprio autor de um polêmico livro sobre a campanha:

...dentro dos próprios batalhões a ação se diluía, para chegar ao emprego de pelotões (40 homens comandados por um 
tenente, três sargentos e um número variável de cabos), talvez explorando a bravura e o espírito de iniciativa dos tenentes... o comandante do I Batalhão, major Carvalho Lisboa... acabou organizando, para seu uso pessoal, um pelotão, que chamou de "Pelotão Especial", composto de homens de sua imediata confiança, com o qual ele intervinha em situações difíceis. Evidentemente esquisito... (...) a unidade de emprego era o pelotão. (BRAYNER, 1968, p. 403-404)

Devemos a esse mesmo Lima Brayner a melhor síntese do que era o perfil socioeconômico da tropa que embarcava para a campanha. Ao subir a bordo do navio-transporte que os levaria ao Teatro de Operações, registrou: “...haviam se escoado inúmeros tubarões filhinhos de papai, poderosos e bem-amparados. A grande massa de mobilizados ali estava porque não conseguira escapar..." Um outro autor (Hélio Silva) refere-se a 300 menores que teriam sido incorporados à $\mathrm{FEB}$ pouco antes do embarque, oriundos do SAM (Serviço de Assistência ao Menor), mantido pelo poder público federal no Estado do Rio de Janeiro. É importante ter em conta que a grande maioria das praças da FEB era oriunda dos mais baixos extratos sociais da nação brasileira. Essa massa de convocados é assim descrita por um dos seus elementos:

Havia de tudo: trabalhadores braçais, motoristas de caminhão, de praça, caixeiros viajantes, vendedores ambulantes e malandros. Cada um deles me contava a sua vida, cada vida era um chorrilho de lutas e um trecho de Zola, e cada história era para mim uma lição que nunca mais esquecerei.... Eles são o povo e, se já não o era, posso dizer que passei a ser um deles, porque vivi entre eles, sofrendo curtindo saudades, e tive a ventura de ser-lhes igual. Não havia distinção, nem de educação nem de côr; éramos todos pracinhas. A guerra tem seu lado bom, ele me fêz ver que todos têm qualquer coisa para se admirar. Os homens, não importa se pobres ou ricos, brancos ou pretos, num determinado momento, são todos iguais perante os próprios homens e perante Deus. (SILVEIRA, 1963, p. 3839)

O problema histórico com que se depara o pesquisador é entender de que forma uma instituição militar como a FEB pode ter logrado êxito em 
um campo de batalha como a Itália na Segunda Guerra Mundial. Maccann (1979), ao findar um catálogo muito sumário das deficiências de organização, seleção, treinamento e equipamento da tropa, bem como seus vícios de origem, concluiu que a sucessão de êxitos da FEB deve ser considerada no mínimo "extraordinária".

O mais incrível é que justamente nesse teatro de operações tudo dependesse da ação (ou inação) de pequenas unidades de infantaria: justamente daqueles grupos social, política e etnicamente heterogêneos de soldados brasileiros, geralmente sob comando de um tenente que, na vida civil, cursava nível superior, a quem os cursos de CPOR (Cursos Preparatórios de Oficiais da Reserva) davam a prerrogativa de cumprir o serviço militar (obrigatório desde 1908) como aspirante a oficial e não como simples soldado. Eram esses militares amadores que representavam a maior parte dos comandantes de pelotão na FEB (CASTELO BRANCO, 1960). A história oficial do $\mathrm{V}$ Exército norte-americano, ao qual a FEB estava subordinada, também o confirma (vide a transcrição de abertura). A guerra nas montanhas da Itália foi uma guerra de infantarias, envolvendo pequenas unidades. Do que elas decidiam ou deixavam de decidir dependia, na sua maior parte, o destino das operações militares. Como a FEB, contrariando toda probabilidade histórica e contra a crença quase unânime dos próprios contemporâneos, converteu-se em força de combate eficaz e até capaz de levar os combates a resultados muito acima das expectativas é uma questão que ainda precisa ser estudada.

Por outro lado, uma reflexão sobre esse tema, a partir de fontes legadas pela História, também pode ser de interesse para os profissionais da disciplina da Psicologia. Para estes, a experiência de uma massa de brasileiros de origens tão distintas, agrupados em três diferentes Regimentos de Infantaria de diferentes Estados do Brasil, composto em sua maior parte por pessoas de baixo nível de instrução e cultura, a maioria da qual submetida há gerações à uma cultura de submissão e resignação, tipificada pelo "se Deus quiser", "o sinhô é quem sabe", “...a senhora é quem manda..." etc., pode lhes ensinar algo diferente sobre como se desenvolve a identidade de grupo e auto-estima suficiente para acreditar que é possível dominar e vencer adversários em combate.

A busca do bom desempenho em combate pelos exércitos de diferentes Estados em todas as épocas sempre foi coisa considerada digna de ser levada a sério. Na sociedade contemporânea e isso pelo menos desde a 
Primeira Guerra Mundial (1914-1918), as autoridades militares puderam contar com a contribuição de disciplinas recém-criadas, como a Neuropsiquiatria e a Psicologia, tanto para incrementar a motivação para o combate e para prevenir a recusa à luta quanto para tratar das doenças mentais associadas aos traumas de guerra. Dessa forma, dois dos trabalhos legados por médicos militares brasileiros, cuja área de atuação variava entre a Psicologia e a Psiquiatria, constituir-se-ão em fontes privilegiadas para esta reflexão. Esses autores podem ser considerados, com toda evidência, como o "ponto zero" da história da Psiquiatria Militar em nosso país. Um dos textos a serem examinados chama-se $O$ posto avançado de Neuro-psiquiatria da FEB, de autoria do criador desse serviço na Campanha da Itália, Dr. Mirandolino Caldas. O trabalho é uma da reconstituição histórica dessa organização médica do exército brasileiro publicada em 1950. O segundo é uma tese apresentada a um concurso de Livre Docência em Clínica Psiquiátrica da Faculdade de Medicina da Universidade Federal do Paraná em 1950 pelo Dr. Rubens de Lacerda Manna, que participou da Campanha da Itália como diretor do serviço de Neuro-psiquiatria da seção brasileira do 7th Station Hospital.

Numa ordem pelos menos igual de importância, tratando do exame dos fatores afetos à motivação para o combate, cabe mencionar também as memórias escritas daqueles indivíduos que efetivamente tomaram parte nos combates. $\mathrm{O}$ testemunho legado em livros e diários sobre a experiência do serviço militar em tempo de guerra e, em particular, sobre a exposição ao combate, é sempre de enorme valor para o processo de compreensão das formas pelas quais é exercida e sofrida a violência no campo de batalha. Contudo, seu uso deve ser precedido de inúmeras cautelas, em especial no que se refere às críticas interna e externa dos documentos, bem como também na aferição da sua objetividade no confronto com outras fontes.

No caso deste artigo em particular, ele foi baseado extensivamente tanto nas memórias pessoais daqueles que tomaram parte efetivamente nos combates como também nas fontes legadas pelos profissionais daqueles ramos da medicina que participaram da Campanha da Itália. Uma discussão sobre os resultados obtidos a partir da comparação dessas com outras fontes escapa aos objetivos deste artigo e será feita mais tarde.

Pretendo que a interpretação dessas fontes, por sua vez, seja feita numa ótica interdisciplinar. As evidências legadas pela Psicologia dos anos 
1940 no seu exercício profissional serão interpretadas a partir do ponto de vista do historiador. Por outro lado, evidências históricas relativas ao comportamento individual e coletivo de soldados brasileiros, tanto no interior dos campos de batalha da FEB quanto no que se refere aos traumas e seqüelas psicológicas decorrentes dos combates, serão interpretadas à luz das categorias usadas pela própria disciplina da Psicologia. Cabe advertir que esta é uma tentativa, quando muito inicial, de lograr a transtradutibilidade do discurso de demonstração de uma disciplina na qual não tenho formação específica (a Psicologia) para o meu próprio (o de historiador). De qualquer forma espero que este artigo logre pelo menos o objetivo de promover e estimular um diálogo entre os profissionais das duas disciplinas que trabalham em instituições de nossa comunidade.

Levando em conta essa diversidade de referências e essa perspectiva interdisciplinar vou tentar interpretar, com base em evidências legadas pelas fontes históricas relativas à participação das tropas brasileiras na Segunda Guerra Mundial: 1) os fatores a que se expõem os seres humanos no que se refere aos perigos do campo de batalha, tanto no que diz respeito ao risco de morte ou invalidez permanente quanto no que se relaciona à tentativa de inflingir os mesmos danos aos seus oponentes; 2) que conseqüências históricas podemos relacionar com a ocorrência dessas experiências em pelo menos um momento considerado decisivo, isto é, de que forma os comportamentos historicamente verificáveis dos combatentes afetaram (ou não) o desenrolar favorável dos eventos subseqüentes. O estudo de caso escolhido é a Batalha de Montese (14 de abril de 1945).

\section{Controlando o medo e forjando a coragem: influência de grupo e autocontrole no campo de batalha}

Mas o fato é que mal ou bem nós - nem todos - conseguimos nem sei como subir em cima daquela primeira encosta, e quando cruzamos o espigão desabrochou em cima da gente aquele mundo de tiroteio. E o pior também é que pouco se via de modo que se atirava pelo rumo ou onde havia um movimento 
ou uma cor que não fosse de terra ou de pedra, e eles, do abrigo, engatilhando, olhando e mandando caprichado. E nós indo, e às vezes o medo é tanto que você pensa "esse é o último passo que eu dou" e dá mais um e diz "agora não dou mais nem um" e vai em frente e diz "agora eu largo tudo e corro" e vai andando "agora chega, eu não sou disso, eu não agüento mais, eu não quero morrer, eu quero voltar para casa" e mais um passo "podem me chamar de covarde que agora eu vou correr" e vai tocando, e vai andando, e vai indo, e bala vindo a gente indo, com a junção do queixo dura, o dente cerrado, a vista meio escurecida em volta enxergando só em frente andando atirando onde podia bala vindo morteiro cessando porque a (terra) deninguém estava sumindo, granada de mão cruzando fuzil e metralhadora comendo solto e cantando e zunindo no ricochete uns nossos se amolecendo no chão varados gemendo estrebuchando rolando varados no chão gritando de dor com um pedaço de metal por dentro, na boca no olho no meio da barriga dentro do rim do intestino gemendo e chorando de dor até morrer gargarejando sangue na boca mastigando bagaços do seu mesmo corpo ou mortos tranqüilos parados olhando manso parados aquela inutilidade de céu" (MELLO E SOUZA, 1973, p. 66-67)

O condicionamento de seres humanos para a batalha envolve um duplo desafio: anular pelo menos em parte os mecanismos conscientes e inconscientes de preservação da própria existência dos indivíduos e, ao mesmo tempo, suspender - e apenas temporariamente - a principal componente do código ético do homem ocidental: a concepção firmemente arraigada de que matar o seu semelhante é errado. Gerar um comportamento agressivo requer tanto a anulação funcional das defesas do indivíduo contra a autodestruição quanto a suspensão (durante o breve período de tempo de sua vida em que presta serviço militar em tempo de guerra) dos tabus religiosos ("não matarás"), jurídicos (assassinato é invariavelmente crime na civilização ocidental) e éticos (que associa o assassinato ao roubo perpétuo daquilo que cada indivíduo tem de mais precioso e absolutamente insubstituível: a própria vida).

Historicamente, uma das componentes centrais do processo de construção social da motivação para o combate verificada é a desqualificação dos inimigos. Todos os meios são válidos (propaganda, educação etc.) para 
disseminar na sociedade uma representação dos inimigos da nação que os exclui da espécie humana. Devemos levar em conta que a própria identidade nacional via de regra é constituída tanto pela identificação quanto pelo contraste - este último geralmente a partir das representações preconceituosas disponíveis sobre os Estados ou povos vizinhos (SEYFERTH, 1990).

Não por acaso, os momentos de mais elevado nível de agressão são verificados justamente entre os combatentes que negam uns aos outros o direito de pertencer à raça humana: o confronto entre o untermensh (subhumano), assim designado pelos nazistas, e a "raça superior" ariana produziu aquele que invariavelmente é descrito como o front mais implacável da Segunda Guerra Mundial: a frente russa (1941-1945). No Pacífico, também são verificadas cenas de extrema violência, tanto por parte de japoneses (que consideravam a todos homens brancos invariavelmente "bárbaros") quanto de norte-americanos (que também relegaram os pequeninos homens "amarelos" à categoria de sub-humanos).

Da mesma forma, mas exemplificando um tipo de exclusão de um determinado grupo das fileiras dos nossos semelhantes a partir de outras ordens de determinações, cabe citar dois exemplos históricos afetos à regulação do uso de determinadas armas por instituições trans ou multinacionais. No que respeita ao primeiro caso, cabe lembrar a ilegalização, por parte do Concílio de Latrão (1139), do uso da besta entre os cristãos na Idade Média, tida como arma cruel e potencialmente perigosa para o status quo daquele período. A primeira característica se explica pela natureza dos ferimentos inflingidos pela ponta de metal de uma flecha metálica que se desloca a alta velocidade. A segunda deriva da constatação de que tal seta era capaz de derrubar um cavaleiro de armadura a pelo menos uma centena de metros.

O que deve ser destacado é que seu uso foi encorajado abertamente pela mesma Igreja Católica contra os assim chamados "infiéis" nas Cruzadas realizadas na Terra Santa. De fato, equipes de besteiros e cavalarianos compunham o essencial das tropas de combate de líderes militares como, por exemplo, o Rei da Inglaterra, Ricardo Coração de Leão.

Um outro caso diz respeito à conjuntura da Corrida Imperialista (1875-1914), que, na Conferência Internacional de Paz de Haia (1899), reuniu, entre outros, representantes e delegados dos governos britânico, francês e russo. Foi deliberada a ilegalização limitada da munição explosi- 
va para armas portáteis (também conhecidas como balas "dum-dum"), que invariavelmente produziam feridas imensas, caracterizadas por ampla destruição de tecidos e hemorragia generalizada. Tais munições foram banidas dos confrontos entre os exércitos europeus, mas tiveram seu uso liberado para os exércitos coloniais. Alegava-se que as munições convencionais não seriam suficientes para deter os ataques nativos, havendo casos de indianos que continuavam a bater-se contra as tropas britânicas com até seis ferimentos de bala. Assim, baseados no contraste de que "o homem civilizado é muito mais suscetível aos ferimentos do que os selvagens... (uma vez que) o selvagem, tal qual o tigre, não é tão impressionável e continua a lutar mesmo se desesperadamente ferido", foi liberado o uso de munição explosiva nas armas portáteis contra aqueles que haviam sido banidos das fileiras da raça humana (O'CONNEL, 1989, p. 280)

$\mathrm{O}$ aspecto mais importante a ser destacado no exame dessas evidências é o papel que essa exclusão desempenha na liberação de um comportamento agressivo. A ampla rejeição ao ato de tirar a vida de seus semelhantes é tão forte na cultura ocidental que somente através da retirada do estatuto do termo "semelhante" aos seus oponentes é que é possível atingir um máximo de comportamento agressivo.

No caso da pesquisa que venho desenvolvendo entre os combatentes da FEB, percebo que a produção social dessa exclusão por parte dos poderes estabelecidos (civis e militares) teve efeitos notavelmente reduzidos. Embora alguns ex-combatentes tenham se referido à "barbárie" nazifascista exercida contra nossa marinha mercante anteriormente à declaração de guerra como força motivadora para seu engajamento no conflito (de fato, a campanha submarina alemã matou centenas de brasileiros, sendo a vasta maioria de civis de todas faixas etárias e ambos os sexos), poucos parecem ter sido impressionados pela propaganda oficial de desqualificação dos nossos adversários. De importância muito maior foi o contato pessoal de nossos combatentes com os civis italianos (BONDESAN, 1947), vítimas da política de deportação forçada da população civil ou represálias contra as atividades guerrilheiras. Ầ medida que avançavam rumo ao norte da Itália, nossos pracinhas viam e ouviam os relatos de massacres, seqüestros em massa, estupros e pilhagens generalizados por parte das tropas de ocupação alemãs, o que certamente contrastava com a sua predisposição 
para se solidarizar com os civis italianos. Contudo, nem isso criou qualquer evidência de que a revolta contra as violências alemãs tenha exercido papel decisivo no que refere à exclusão dos nossos adversários das fileiras da raça humana. Muito pelo contrário, existem indícios suficientes para afirmar que nossos combatentes tendiam em geral a considerar o soldado alemão como um seu equivalente, que estaria lá para cumprir um papel idêntico ao deles: lutar pelo seu país, cumprir ordens etc.

No grupo tinha um soldado que xingava os alemães mortos que via, um mato-grossense tipo de mato. Mas ele não compreendia que o alemão estava cumprindo o dever dele, da mesma forma que nós estávamos cumprindo o nosso. Apesar que no nosso caso procura se justificar que estávamos corrigindo um mal, que seria o que os alemães estavam praticando. Mas isso na opinião deles era um bem, por estarem revoltados com Versailles. Então eu achava que éramos iguais, e discutíamos isso entre os sargentos. Humanamente, isso nivelava a gente. (MAXIMIANO, 1995, p. 61)

O front italiano jamais se constituiu em referência de brutalidade no que se refere aos trato com os prisioneiros de guerra. Embora confrontos encarniçados tenham conduzido a extremos de ferocidade entre os combatentes, não há registro de execuções sumárias ou maus tratos deliberados para com prisioneiros, inclusive entre os brasileiros (CAMPIANI, 1995) e seus adversários (WAACK, 1995). Contudo, a perda de companheiros por ação inimiga podia levar a reações as mais extremas, como percebemos abaixo:

...no começo, era uma sensação estranha disparar na direção do inimigo, pois a consciência sempre batia para me lembrar que eu estava ferindo alguém. Depois que o primeiro companheiro morreu, atirávamos com vontade, desejando que cada projétil atingisse o alvo. (MAXIMIANO, 1995, p. 62)

Tais evidências ajudam a avançar na questão de como foi possível, de forma eficaz e controlada, fazer com que soldados de diferentes forças 
armadas pudessem ser induzidos a agirem com intensa brutalidade no que se refere a usar de agressividade uns contra os outros. Mas se a raiva, seja derivada da exclusão cultural dos adversários das fileiras da raça humana, seja resultado da dor da perda, é um sentimento a se levar em conta, mais ainda o é o medo. Como é que os soldados se tornam capazes de controlar seus medos e fraquezas e conseguem resistir às tensões da batalha? O que sabemos da forma pela qual conseguiram - e conseguem - fazer com que, a despeito de tudo o que o indivíduo sabe a respeito dos riscos inerentes ao campo de batalha, nele permaneça? E, finalmente, qual o risco a que se expõem os homens que avançam sobre os seus oponentes dispostos a tirarlhes a vida para lograr atingir seus objetivos?

Numa palavra, o que está em questão é o entendimento das formas pelas quais o medo se manifesta e como ele é evitado no decorrer dos conflitos armados. A diversidade de estratégias adotadas voluntariamente para controlar o medo, identificadas pela psiquiatria militar brasileira, é exemplificada no trecho abaixo, de autoria do já citado Rubens de Lacerda Manna:

\footnotetext{
O soldado se defende do mêdo lançando mão de recursos imaginosos ou de racionalizações. Surge em alguns a idéia da fantasia de invulnerabilidade e se apegam a amuletos, orações, com que se julgam protegidos. Em outros domina o sentimento de fatalismo. Em indivíduos menos inteligentes, que não avaliam corretamente a realidade, o perigo é subestimado, apesar de sua ameaça gritante. Outros, como que se expõem com certo prazer ao perigo, parecendo desejar inconscientemente serem feridos (MANNA, 1950, p. 15)
}

A explicação mais usual para a superação do medo, que é prérequisito para a materialização do comportamento agressivo no campo de batalha, diz respeito à coação: seres humanos se entregam ao exercício de matar e morrer porque são coagidos pela disciplina militar. É bem conhecida a frase de Frederico II, Rei da Prússia, que criou enorme reputação como líder militar no século XVIII, de que "o soldado comum deve temer muito mais aos seus oficiais de que ao inimigo". Seria através da imposição do princípio da obediência aos seus superiores, largamente baseado na violência ou na ameaça de seu uso, que pessoas comuns se submeteriam às cir- 
cunstâncias e eventos de caráter traumático e fundamentalmente violentos como aqueles que são inerentes ao campo de batalha.

Outro conjunto de explicações se refere à persuasão. Aqui, a motivação para o comportamento agressivo que se espera dos militares no campo de batalha deriva da adesão a determinados valores, a busca de recompensas materiais e simbólicas ou a instilação de determinadas formas de comportamento. O patriotismo, a busca de glória militar, a necessidade de defender o território, a oportunidade de promoções e prêmios, incluindo aí saque e pilhagem, vinganças pessoais ou a preservação da honra nacional ultrajada seriam os valores e idéias mais recorrentemente associados à adesão dos soldados comuns ao exercício eficaz das operações militares em tempo de guerra. Naturalmente que ambas as ordens de motivação (coação e persuasão) não são excludentes. Pelo contrário, a literatura militar demonstra à exaustão que praticamente todos os exércitos conhecidos lançaram mão desses dois tipos de motivação, ainda que em diferentes proporções, para garantir que seus soldados cumprissem as suas missões em tempo de guerra.

A despeito da importante contribuição que essa produção historiográfica nos legou para entender as motivações para a materialização dos comportamentos agressivos inerentes aos campos de batalha, ela ainda se refere a um nível demasiado elevado de abstração. É que, para além da compreensão da importância do uso da coação e da persuasão, é importante levar em conta que o essencial da historiografia militar se refere à ação de grandes unidades, como grupos de exércitos, exércitos, divisões etc.

Contudo, a despeito dessa ênfase no estudo da ação das grandes unidades, sabemos que soldados se organizam em pequenos grupos para lutar. As guarnições de carros de combate e de peças de artilharia reúnem, via de regra, menos de meia dúzia de indivíduos. Os grupos de combate tem, em geral, uma dúzia de soldados; pelotões, quatro dezenas; companhias, cerca de duas centenas; e um batalhão pode chegar a quase 900 homens. São essas pequenas unidades que travam os combates a mais curta distância com o inimigo e é sobre elas que devemos deter nossa atenção se quisermos fazer avançar nosso conhecimento sobre as razões que fazem com que os seres humanos desempenhem a contendo o papel de algozes de seus próprios semelhantes ao mesmo tempo em que se expõem a um risco mortal. É aqui que se torna útil o exame da contribuição da Psicologia, a partir de Freud, para entender as implicações da produção social desse comportamento agressivo a partir dos grupos. 
Freud divide a mente humana em três elementos chave: o Id é a parte mais primitiva, contendo todas as funções de natureza instintiva, os conteúdos do $I d$ não alcançam o nível de consciência, mas se manifestam sob a forma de sonhos e sintomas neuróticos; o ego é um desenvolvimento do $I d$, que o liga ao mundo exterior, a maior parte das atividades do ego são conscientes, ele assimila e retém estímulos externos e controla nossas atividades voluntárias; finalmente, o super-ego diz respeito aos códigos de moral e padrões de comportamento, este é formado no início da nossa vida, através da influência inconsciente da ação de pais e professores. O Id é formado pelo princípio do prazer e o ego pelo princípio da realidade, e o conflito pode ocorrer entre eles, como por exemplo, os mecanismos de distorção da realidade, que surgem como parte dos instrumentos de defesa do ego.

Partindo de Freud ou da experiência prática do dia-a-dia das instituições militares, podemos entender que tanto o conjunto de valores afetos às normas e culturas de determinado grupo social quanto as reações instintivas do indivíduo à sua própria preservação terão de ser levadas em conta se quisermos entender as reações dos indivíduos ao ambiente do campo de batalha. É aqui que o correto entendimento da organização dos indivíduos em grupos destinados a desempenharem um comportamento agressivo ganha importância.

A compreensão da importância do grupo no que se refere ao comportamento agressivo no campo de batalha começa quando levamos em conta a hierarquia de necessidades dos indivíduos devida a Freud. Presumimos que em todos os indivíduos exista uma necessidade por comida, bebida e sono, a qual acaba levando a busca de segurança e proteção. Daí, entendemos o sentido da vida em grupo e suas correspondentes gratificações sociais, como o sentimento de pertencimento, atividades coletivas e a busca do lazer. Num nível seguinte, temos as necessidades afetas à autoestima, como status e reconhecimento social. Finalmente, um nível mais abstrato de necessidades é aquele que diz respeito à auto-realização, com as correspondentes necessidades por crescimento, desenvolvimento pessoal e poder de realização. Como é possível prever, esse conjunto de atitudes e expectativas afetam não só o relacionamento dos indivíduos com o grupo, mas também a sua atitude diante dos líderes desse mesmo grupo.

Presumimos que o processo social de identificação do indivíduo com o grupo é construído progressivamente, através da experiência concre- 
ta do dia-a-dia, em que ele pode perceber tanto consciente quanto inconscientemente que é através da sua aceitação pela coletividade que ele irá lograr obter a proteção e a segurança de que necessita. Mais ainda, para além da sobrevivência física propriamente dita, o grupo é a unidade social capaz também de forjar o sentimento de pertencimento, propiciando o reconhecimento coletivo e a realização social almejada individualmente pelos seus membros.

No que se refere ao a lograr esses objetivos, ganham importância central dois aspectos: a forma como o grupo é criado e mantido e o papel organizacional desempenhado pelas lideranças, em particular pela liderança imediata a que está submetido o indivíduo. A relação do indivíduo com o grupo e seus líderes é descrita por um psiquiatra militar da Força Expedicionária Brasileira da forma abaixo:

Este "sentimento de grupo" constitue elemento da maior significação, principalmente nas condições de combate, para o equilíbrio e estabilidade da personalidade do soldado. Como elemento construtivo do seu grupo, o soldado sente-se mais forte e mais resistente para enfrentar todas as situações. Se perde a relação com os seus companheiros diretos, sente-se desamparado. Os laços emotivos que o prendem fortemente ao seu grupo, constituem a fôrça dominante construtiva da sua capacidade como combatente. A vida do grupo é a sua própria vida. A ruptura da unidade do grupo, constitue mesmo causa primária da desorganização da personalidade do soldado. A manutenção do equilíbrio psíquico, a defesa contra a voragem do mêdo, tem o seu ponto de apóio emotivo mais forte no apego pessoal e na unidade do grupo. A pêrda de um camarada, seja um superior amigo e respeitado, seja a um comandado, que esteve servindo sob as suas ordens, constitue para o combatente, muitas vezes, um traumatismo psíquico mais forte e mais doloroso, do que o de ser varado por um projetil inimigo. (MANNA, 1950, p. 26)

O primeiro grupo social a que se liga o indivíduo é a própria família. É o grupo de maior importância para o processo de constituição da identidade e personalidade de qualquer pessoa. Contudo, mesmo a ligação familiar tende a se obscurecer ou mesmo fraturar diante dos vínculos forjados entre indivíduos que travam combates letais. Uma das passagens mais 
elucidativas nesse sentido é da obra do ex-combatente alemão Erich-Maria Remarque. Em seu clássico Nada de novo no front, publicado no imediato primeiro pós-guerra, o autor descreve a irrealidade e o artificialismo da sua licença do front em casa. Em nenhum momento ele podia deixar de pensar que seria mais útil e reconfortante estar em presença de seus camaradas no front ao invés de dedicar-se a futilidades como as conversas com seus familiares ou os programa sociais com seus antigos amigos. Todo tempo sua mente se voltava para o pensamento de que seus camaradas de trincheira podiam estar precisando dele, tanto quanto ele próprio precisou daqueles em tantas ocasiões. Outra passagem representativa do fenômeno refere-se ao conhecido filme de Spilberg, $O$ resgate do soldado Ryan. Refiro-me à cena em que o próprio soldado Ryan é comunicado de que faz juz à retirada imediata do front, face à perda quase simultânea de todos seus três irmãos em combate. Mesmo estando fisicamente esgotado e em um posto extremamente exposto, ele se recusa a partir, argumentando que: "....afinal de contas os únicos irmãos que eu tenho agora são esses aqui em volta...”

O entendimento do papel desempenhado pelo grupo no controle e na superação do medo demanda previamente o exame de uma breve lista dos perigos e riscos a que está sujeito o combatente, bem como a indicação de algumas das reações possíveis a estes.

Cumpre notar que são justamente as reações ao medo e suas conseqüências que ocupam o centro das atenções da Psicologia Militar em tempo de guerra. Tais reações tem grande variedade e se devem a uma multiplicidade de eventos relacionados tanto à batalha propriamente dita quanto aos momentos que a antecedem e sucedem.

De saída, cabe mencionar as reações afetas às fobias a determinados tipos de armas, como aconteceu com a metralhadora alemã MG42, conhecida como "lurdinha", "rasgapano" etc. A origem de tais apelidos muito provavelmente se relaciona com a elevada cadência de tiro dessa arma, superior ao de qualquer outra. Além de muito precisa e de grande alcance, essa arma tinha um sistema de troca de canos extremamente eficiente, o que permitia atenuar o problema do superaquecimento, que é comum a toda arma automática. Somemos a esse fato a proporção de metralhadoras e outras armas automáticas de um exército em relação a outro. Em 1944, as divisões de infantaria alemãs com efetivos completos, que eram uma minoria, contavam com 12.500 homens em comparação com os mais de 15.000 de uma divisão de infantaria típica norte-americana. Mas a tropa 
alemã podia contar com mais de 650 metralhadoras. Em contraste, os norte-americanos possuíam apenas 157 metralhadoras leves e 236 pesadas. Cada grupo de combate (12 homens) alemão contava com pelo menos uma metralhadora, ao passo que uma companhia norte-americana de 120 homens tinha apenas duas metralhadoras de calibre médio (.30 pol.) (MANSOOR, 1999, p. 149).

Para além do fogo das armas automáticas, também o bombardeio de artilharia e morteiros de todos os calibres foi capaz de produzir inúmeros casos de baixas psiquiátricas. A exposição ao barulho e ao deslocamento de ar das explosões e o arremessar de estilhaços de metal em todas as direções produziam medo intenso e constante, o qual conduzia à paralisia, à prostração e ao sobressalto permanentes. Se a exposição aos efeitos do fogo de artilharia inimiga fosse de fato intensa ou próxima, ela se faria notar sobre a própria constituição física do indivíduo. Foram comuns os casos de hemorragias mais ou menos extensas nos pulmões por efeito do súbito e brutal deslocamento de ar provocados pelas explosões. Percebemos, aí, o desafio posto ao autocontrole dos combatentes quando expostos aos bombardeios inimigos.

O mesmo se dava com as minas terrestres. Mesmo "os mais valentes" (BRAYNER, 1968) de nossos combatentes encontravam enorme dificuldade em superar o medo paralisante de que se viam acometidos quando sabiam estar pisando terreno minado. Um cabo mineiro (sapador) encarregado da tarefa de desativar minas e outras armadilhas explosivas dos caminhos e acessos por onde nossas tropas passariam relata os perigos envolvidos em seu trabalho:

Veja a mina S por exemplo. S era S de schrapnel. Essas iniciais sempre queriam dizer alguma coisa. Só uma é que eu nunca fiquei sabendo. Uma que eu só conheci nos fins da guerra e que era uma das mais importantes. Acho até que era a mais importante de todas: a mina R. Até hoje não sei o que é que aquele $\mathrm{R}$ queria dizer. Mas também não adiantava porque aquela era proibido desarmar. E tinha minas muito bonitas. A holz que era uma caixa de madeira colorida. Eles faziam minas de madeira para o detetor não pegar você sabe: o detetor só acusa metal. A rampa húngara que era uma mina medonha. Para desarmar era fogo. O buraco do pino ficava encoberto de modo que você tinha que puxar a cabeça do percussor até ele 
aparecer. Agora, se você puxasse coisa de meio centímetro a mais ela estourava, já pensou? E o ZUZZ 35 ainda era pior. Se você puxasse o percussor um nadinha a mais ele arrebentava. Mas se você cortasse o trip-wire ele arrebentava também. Puxando ou largando aquilo funcionava. Perigosíssimo. E os de tempo então? Quando eles armavam, o detonador começava a funcionar para estourar num tempo regulado que você não sabia qual era. De modo que quando você ia desarmar você desconhecia se faltava muito, se faltava pouco ou se já estava na hora. Vai só pensando. Meu querido, pode acreditar: mexer com mina é fogo. Fogo. Tinha umas granadas italianas chamadas diavolo rosso que eles ativavam com um detonador e que quando estouravam te polvilhavam o corpo de farpas de aço que era o recheio delas. E tinha uma mina estaca que quando explodia os estilhaços eram de concreto. Machucava que era um horror. E tinha umas do tamanho de um lápis que só te arrancavam os dedos, veja você. E tinha um não acabar mais e tudo aquilo funcionava se você pisasse ou se você puxasse ou se você erguesse ou se você balançasse e eu acho que devia ter alguma que arrebentava se você pensasse nela. Por isso... estudava na escola de minas. Conhecia todas. Quase todas... (MELLO E SOUZA, 1973, p. 76)

Outra atividade que merece ser mencionada é a das patrulhas e movimentos ofensivos executadas à noite, em terreno montanhoso e minado, coberto com neve, que foram fatores de grande desgaste emotivo. Ao cansaço físico somava-se o cansaço mental, produto de horas seguidas de tensão e expectativa, na qual os órgãos dos sentidos eram exigidos ao máximo e em circunstâncias em que uma imprecaução ou descuido poderiam ter as mais imprevisíveis consequiências. Compreendemos aí que o tempo de permanência do soldado na linha de frente seja, em geral, mais breve do que imaginamos, sendo entremeado de períodos mais ou menos prolongados de repouso na retaguarda imediata da linha de frente. Os norte-americanos tentavam manter suas tropas na linha de frente entre 20 e 30 dias, freqüentemente por até 40 dias e eventualmente 80 dias, apesar de haver o registro de um regimento de infantaria do $\mathrm{V}$ Exército norte-americano que ficou mais de 90 dias em linha (justamente o $6 .^{\circ} \mathrm{RI}$ da $1 .^{\mathrm{a}}$ Divisão de Infantaria Expedicionária - FEB). 
O resultado da exposição a esses elementos fatalmente tem suas consequiências, sendo a pior delas o colapso total do indivíduo. Abaixo, verificamos a incidência de casos psiquiátricos da FEB a cada mês da campanha, segundo a tipologia da época.

QUADRO 1 - NÚMERO DE PACIENTES ENTRADOS NO POSTO AVANÇADO DE NEURO-PSIQUIATRIA (PANP) DE SETEMBRO DE 1944 A MAIO DE 1945

\begin{tabular}{|lccl|}
\hline mês/ano & 1. ${ }^{a}$ admissão & readmissão & total \\
setembro de 1944 & 18 & 0 & 18 \\
outubro de 1944 & 11 & 1 & 12 \\
novembro de 1944 & 40 & 2 & 42 \\
dezembro de 1944 & 68 & 3 & 71 \\
janeiro de 1945 & 58 & 2 & 60 \\
fevereiro de 1945 & 58 & 4 & 62 \\
março de 1945 & 61 & 15 & 76 \\
abril de 1945 & 34 & 7 & 41 \\
maio de 1945 & 2 & 0 & 2 \\
SOMA & 350 & 34 & 384 \\
\hline
\end{tabular}

FONTE: Caldas, 1950.

A partir da leitura dessa tabela, percebemos que, do ponto de vista das baixas por causas psiquiátricas, o pior período corresponde aproximadamente ao inverno (novembro a março), o qual também foi caracterizado pelas sucessivas tentativas fracassadas e dispendiosas de tomada do Monte Castelo. O mês de abril de 1945 se caracteriza pela Ofensiva de Primavera, a qual pôs fim à guerra na Itália. Contudo, nesse mesmo mês, num único dia (14), a FEB sofreu mais baixas em combate tentando a tomada da cidade de Montese que em todos os ataques ao Monte Castelo. A tabela abaixo revela as causas das baixas psiquiátricas. 


\section{QUADRO 2 - ENTRADA DE COMBATENTES NOS POSTOS DE ATENDIMEN- TO PSIQUIÁTRICO BRASILEIROS POR DIAGNÓSTICO SEGUN- DO O PANP}

Estado de anciedade .............................. 102

Histeria (ataques) ................................... 33

Histeria (estupor emotivo) ..................... 3

Histeria (paralisia) .................................. 2

Histeria (alucinações oníricas) ............... 2

Histeria (surdo-mudez) ......................... 1

Histeria (amaurose) .............................. 1

Organo-neurose …................................... 30

Fobia de obuzes ....................................... 33

Fobia do fronte ...................................... 20

Fobia de metralhadora .......................... 8

Fobia de tiros .......................................... 4

Personalidade psicopática ....................... 11

Neurastenia emotiva ................................. 7

Esquizofrenia ........................................... 5

Esquizomania ....................................... 1

Estado maníaco ......................................... 1

Depressão melancólica ........................... 3

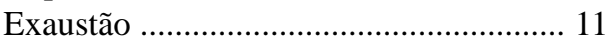

Alcoolismo ............................................ 8

Epilepsia .................................................. 4

Deficiência mental .................................. 5

Deficiência mental-inversão sexual ......... 1

Sentimento de inferioridade .................... 3

Concussão cerebral ................................... 2

Confusão mental ........................................ 3

Síndrome paranóide .............................. 3

Gagueira emotiva ................................. 2

Nevralgia facial ......................................... 1

Caimbra profissional ............................ 1

Síndrome parkinsonoide ........................... 1

Simulação de ataques epilépticos ........... 20

Simulação de psicose .............................. 5 
Simulação de amnésia ............................ 1

Simulação de tubérculos ......................... 1

Simulação de insônia ............................... 1

Não diagnosticado ................................... 5

FONTE: Caldas, 1950.

Contudo, muito antes de se tornar uma baixa psiquiátrica, os soldados vivem todo tipo de distúrbio de natureza psicológica, mas de uma natureza considerada "menor". Vejamos, por exemplo, a listagem abaixo:

1. Irritabilidade crescente, manifestada por irrequietude, reação exagerada a pequenos incidentes e condicionando atritos freqüentes. Tendência à pornografia, a atos de violência, queixas sem motivo. Explosões de raiva, uso exagerado do fumo.

2. Acompanhando este estado de "hipersensibilidade" a estímulos externos insignificantes, se tornam aparentes os sintomas de um tipo de reação especial, denominada pelos americanos de "startle reaction", que poderia ser chamada, por nós, de "reação de alarme, ou "reação de susto". Consiste essencialmente em respostas motôras involuntárias, exageradas, visando autoproteção, diante de ruídos repentinos ou de um excitante, luminoso súbito. O indivíduo como que mostra constantes sobressaltos, se abaixa, se encolhe, pula salta, contrai-se, diante esses estímulos.

3. As perturbações do sôno se associam quase sempre. Consistem na impossibilidade de conciliar o sono mesmo quando as condições militares o permitem. As oportunidades para repouso são raras e a impossibilidade de desfrutar um sôno torna-se torturante. Quando é possível adormecer, o sôno é sempre entrecortado e dificultado por pesadelos, aterrorizantes sonhos em que são revividas cênas de batalha. (MANNA, 1950, p. 24)

De acordo com a experiência acumulada pela psiquiatria militar brasileira durante a Segunda Guerra Mundial, estes seriam os sinais incipientes da exaustão de combate, os quais poderiam, contudo, se prolongar por semanas ou meses ou então irromper em algum incidente que transformasse $o$ militar em uma baixa psiquiátrica. Havendo outros distúrbios precedentes de personalidade, os sintomas se agravam, assumindo as seguintes formas: 
1. Fadiga excessiva, diminuição do interesse, falta de estímulo, incapacidade para transmitir as ordens, esquecimento fácil, dificuldade e grande lentidão para executar atos comuns habituais, traduzindo um retardamento locomotor geral e apatia. 2. Mudança de humor e de atividade, com tendência ao isolamento (um indivíduo expansivo se torna tristonho e calado); crises de chôro e depressão. Calma aparente em um soldado que não tem essa tendência; chegando às vezes a estados de estupor e imobilidade.

3. Descuido consigo próprio, abandono do seu equipamento, desinteresse pela alimentação, pela sua situação, pelas cartas que lhe chegam de casa.

4. Crise de pânico, com fugas, nomadismo, exposição a riscos desnecessários, com estados crepusculares de consciência e certo grau de confusão mental.

5. Queixas somáticas, tremor, taquicardia, dores pelo corpo ("reumatismo"), dores precordiais, náuseas, diarréia, sudorése excessiva. Distúrbios da visão ("vista escura"). Torturas, estado vertiginoso. Cefaléia. Micção frequente, enureses, poluções repetidas. "Fôlego curto", falta de ar. Palidez ou enrubecimento do rosto. Cianóse das estremidades e dos lábios, com tendência a lipotimia ou a desmaios. Tudo sem uma base orgânica demonstrável. (MANNA, 1950, p. 25) (grifo meu)

Esses fatores concorrem para que o soldado se mostre ineficiente e crie conflitos. A mais grave manifestação do ponto de vista da eficiência militar é a passividade. Esta pode ser forçada diante do fogo inimigo, que obriga a tropa a ficar inativa debaixo de cerrado bombardeio, sem poder revidar o ataque. O contacto prévio com forças concussivas pode traumatizar a tal ponto o soldado que ele se torna inoperante, mesmo quando a intensidade do bombardeio não oferece maior risco. Esse sentimento de falta de proteção diante do bombardeio raramente pode ser contrabalançado pela solidariedade do grupo, uma vez que a dispersão dos indivíduos no campo é pré-condição para a sua sobrevivência.

Essa passividade pode ser exercida de forma inconsciente, desde que se inicie o processo de exposição às sensações visuais e auditivas intensas, como o silvo das granadas e explosões, fenômenos sempre associados ao bombardeio. Contudo, é comum que essa passividade seja também adotada como reação aprendida a uma ameaça iminente, numa atitude associada aos reflexos. Estes permanecem ativos entre os indivíduos mesmo 
após passada a guerra. Vejamos o depoimento de um ex-combatente recémchegado a Curitiba após o término das hostilidades:

...quando atravessávamos a Praça Tiradentes, dei o vexame. Havia ali uma parada de bondes. Ao passarmos pelo local, um deles foi saindo e quando o motorneiro solta o freio, há aquele chiaço que todos conhecem. É muitíssimo parecido com o assobio de uma granada de morteiro de 88 , dos alemães. Pois, meus reflexos ainda funcionavam perfeitamente. Distraído como ia, atento à pergunta de um dos repórteres, quando dei por mim estava agachado debaixo da carroceria de um caminhão... eu confundira o ruído do freio hidráulico com o sibilar de uma granada de morteiro 88. (PISKE, Florianópolis, FCC, 1984, p. 231).

Outros sintomas associados aos traumas, stresses e esgotamentos típicos das atividades militares são o declínio geral da vida intelectual provavelmente relacionada à monotonia dos cenários. Tanto dentro quanto fora dos combates, é possível viver intenso desejo de fuga. Para aqueles diretamente envolvidos no combate, é recorrente o sentimento de culpa, por ter matado e ter que matar. No caso da FEB, foram observados também efeitos deletérios relacionados ao isolamento nos buracos de trincheira. Inúmeros distúrbios de diferentes durações tiveram como causa a má adaptação à dieta militar, a privação de alimentos. Igualmente perturbadores eram a falta de notícias de casa, a falta de repouso, com resultante fadiga crescente. Tanto as más notícias de casa (em especial no que se refere aos casados) quanto a privação sexual e de companhia feminina também tiveram efeitos sobre o equilíbrio emocional dos combatentes. A distância de casa deve ter sido ainda mais difícil de ser suportada por aqueles que padeciam de compreensão e convicção insuficientes quanto à necessidade de lutar.

Para além dos sintomas associados à depressão, foi constatado todo um catálogo de efeitos relacionados ao medo, fosse constante, fosse súbito. Destes, o pior parece ter sido o medo de demonstrar medo. Esse autêntico pavor gerava toda sorte de distúrbios psicológicos e suas correspondentes manifestações de caráter somático. Essas ocorrências parecem ter sido particularmente intensas entre aqueles que adentraram no conflito com um súbito aumento de responsabilidade, como o caso dos oficiais reservistas. A 
eles cabia, numa proporção média de $49 \%$ dos efetivos de oficiais, a condução dos pelotões para a batalha (MORAIS, 1947; ARRUDA et al., 1947, CASTELO BRANCO, 1960). Nestes, o receio de se mostrar acovardado, de demonstrar medo, devia-se ao fato de que a sua liderança e autoridade se deviam ao exemplo de que fossem capazes de dar aos seus comandados. Com efeito, comandantes de pequenas unidades se obrigam a um grau de exposição superior à média, sofrendo as conseqüências sob a forma de um número de baixas desproporcionalmente elevado.

Outra força de desmotivação para o combate foi a relação com o comando. Disseminou-se na FEB a idéia de que o seu comando era pouco capaz, o que despertava nos homens desconfiança sobre o valor das ordens. Tal avaliação podia conduzir a um sentimento de revolta, em especial se as ordens superiores julgadas erradas fizessem com que companheiros fossem feridos, mutilados e mortos. Geralmente, essas circunstâncias podiam também levar a um sentimento de culpa por ver companheiros feridos morrerem, sem que pudessem ser socorridos. Todos esses fatores podiam fazer o combatente perder o controle sobre si mesmo, fazendo dele uma baixa psiquiátrica. Essa situação era mais freqüente no caso de militares com responsabilidade pela vida de outros, como foi o caso dos comandantes de pequenas unidades.

Um estudo sobre a coragem e o medo: a FEB e outras tropas do V Exército Americano na Campanha da Itália

Os nisseis do $100{ }^{\circ}$ batalhão e do $442 .^{\circ}$ Grupo Regimental de Combate sabiam que lutavam para redimir seus pais e amigos em casa de uma perseguição injusta (refere-se ao internamento maciço das populações nipo-americanas em campos de concentração na costa leste dos EUA), assim esses homens deitavam fora suas vidas sob as metralhadoras alemãs num abandono quase pródigo. Do outro lado, os negros da $92 .^{\mathrm{a}}$ divisão, insuficientemente motivados para a luta, não desempenharam tão bem quanto se esperava. Entre esses extremos estava a grande massa dos soldados do V Exército, 
lutando bem e cuidadosamente, rapidamente se tornando veteranos... o V Exército teve os menores problemas com os brasileiros, treinados e equipados no padrão norte-americano, um contingente que não era muito grande e que não foi empregado em partes importantes da linha; as principais dificuldades enfrentadas foram o insuficiente treinamento recebido pelas unidades brasileiras antes da chegada na Itália e a sempre frouxa disciplina no que se refere aos suprimentos dos soldados brasileiros tomados individualmente. (STARR, 1947, p. 443-444)

Conforme nos referimos, o aspecto mais paradoxal da história da FEB é que essa tropa acabou por desempenhar bem suas tarefas da campanha da Itália, a despeito de inúmeras falhas no processo de mobilização, recrutamento, seleção médica, treinamento e comando no campo de batalha, para não mencionar os erros do comando. Contudo, parece haver um razoável consenso de que a FEB desempenhou a contendo as suas missões no teatro de operações da Itália durante a Segunda Guerra Mundial, mesmo levando em conta o fato de que era uma única divisão de infantaria, atuando, inicialmente, nas partes menos importantes de um teatro de operações secundário. Refiro-me a dois indicadores desse desempenho. $\mathrm{Na}$ ofensiva final das tropas aliadas na Itália, a 1. ${ }^{\mathrm{a}}$ Divisão de Infantaria Expedicionária desempenhou papel de relativa importância na ruptura das linhas inimigas (Montese, 14 de abril de 1945). Na perseguição final, surpreendeu o próprio Comando Aliado ao cercar e capturar toda uma divisão de infantaria alemã (a 148. ${ }^{a}$ ) após renhidos combates (Fornovo, 28 de abril de 1945). O exame dos fracassos da FEB, por outro lado, também mereceu extensa literatura (ARRUDA, 1950; BRAYNER, 1968), em particular no que se refere às sucessivas tentativas de tomada do Monte Castelo (novembro e dezembro de 1944), afinal capturado em 21 de fevereiro de 1945.

Entre os dois extremos, isto é, a coragem "fanática" dos nipo-americanos e o fiasco quase total da divisão de negros norte-americanos (também conhecida como "Buffalo Soldiers"), está a FEB, com um rol de fracassos (quatro tentativas para tomar o Monte Castelo) e pelo menos um grande vexame (a fuga em massa da linha de frente, num quadro de histeria coletiva, $o$ qual se abateu sobre o $1 .{ }^{\circ}$ Batalhão do $11 .{ }^{\circ} \mathrm{RI}$ na fatídica noite de 2 de dezembro de 1944), mas capaz de lutar honrada, eficaz, corajosamente e talvez até 
atuando de forma decisiva em pelo menos duas ocasiões (Montese e Fornovo), já referidas acima.

A comparação da FEB com a 92. ${ }^{a}$ Divisão já foi feita em outra ocasião, de forma que não irei repetir os argumentos já trabalhados em outro texto. ${ }^{1}$ Contudo, julgo oportuno fazer aqui uma comparação entre a FEB e os nipo-americanos no que diz respeito às questões afetas à motivação para o combate, em particular no que se refere a sentimentos como a honra, vergonha, medo e pertencimento ao grupo.

Já em julho de 1944, a imprensa dos EUA demonstrava sua estupefação com o fato de os nipo-americanos serem capazes de lutar tão "fanaticamente" pelos EUA quanto os japoneses eram capazes de lutar contra ele. (DUUS, 1987, p. 128) Sua reputação de combatentes leais e audazes não precisou esperar o fim da guerra para se tornar conhecida. Isso não quer dizer que os japoneses estivessem livres dos traumas e outros problemas psicológicos que afetavam ao conjunto dos combatentes da Segunda Guerra Mundial.

Os primeiros informes de traumas relacionados à exposição aos bombardeiros ("shell shock") entre os nisseis norte-americanos datam das tremendas batalhas por Monte Cassino (1943). Em contraste com outras unidades, houve poucos casos desses traumas. A resposta usual a esse fenômeno dada por muitos veteranos se refere ao espírito japonês (Yamato damashii). Vivendo num país estrangeiro, os japoneses teriam inculcado em seus filhos e netos os valores éticos que eles aprenderam durante sua educação no Japão. Os japoneses teriam ensinado aos seus filhos nascidos nos EUA não somente o valor do trabalho duro, mas também a ética da vergonha e o valor do nome da família. Os nipo-americanos, especialmente aqueles originários do Hawaii, vieram em sua maioria da mesma ilha, das mesmas cidades e plantações que seus irmãos, primos e amigos. "Vergonha" no campo de batalha significava "vergonha" para suas famílias. O que os seguiria para o resto das suas vidas.

A questão da vergonha não é a única explicação para a baixa taxa de colapsos psicológicos no campo de batalha. Os nipo-americanos podem ter tido um senso de propósito mais forte do que os dos outros soldados dos EUA. Eles estavam lutando não somente para defender seu país,

1 MAXIMIANO, C. C.; OLIVEIRA, D. de. Raça e Forças Armadas: o caso da Campanha da Itália (1944-45). Revista Estudos de História, São Paulo, v. 8, n. 1, p. 157-184, 2001. 
mas para provar aos seus patrícios e companheiros que eles eram americanos leais e patriotas. Esse forte senso de propósito foi um escudo contra as tensões e medos do campo de batalha.

Entre os nipo-americanos, o espírito de camaradagem era também forte. A solidariedade entre os jovens, arriscando suas vidas para provar seu americanismo, foi incomparavelmente mais intensa do que em outras unidades. Praticamente nenhum nipo-americano foi levado à corte marcial. Insubordinação perante os oficiais ou pequenas transgressões do código penal militar eram questões que diziam respeito apenas a eles próprios. Tampouco os nipo-americanos abandonavam os seus companheiros, mesmo os mortos. Somente na Batalha de Monte Cassino (1943), quando não havia outra escolha, é que eles abandonaram os corpos de seus companheiros no campo de batalha. (DUUS, 1987, p. 127)

Já no que diz respeito à $\mathrm{FEB}$, o caso mais curioso se refere ao primeiro batalhão do $11 .^{\circ} \mathrm{RI}$. O1. $/ 11 .^{\circ} \mathrm{RI}$ chegou à linha de frente na noite de 2 de dezembro de 1944 e, segundo as pesquisadoras Andréa Bochnia e Laura Thomé2

...tendo tido seu treinamento abreviado, o que o fazia quase inexistente. $\mathrm{O}$ regimento permaneceu quarenta dias na área de estacionamento submetendo-se a um programa de instrução segundo nos informa o general Delmiro Pereira de Andrade, seu comandante, tendo participado com algumas de suas companhias de escaramuças com o inimigo. Com a chegada da noite, a rotina de "provocações" realizadas pelos alemães, o "golpe de mão", o "ataque", ou o que quer que tenha sido, assumiu proporções descabidas na perspectiva desses brasileiros inexperientes, fazendo com que abandonassem suas posições em uma onda de pânico que atingiu do soldado ao comando, provocando uma debandada geral.

Esse batalhão foi alvo, a partir daí, de toda uma serie de cuidados por parte do comando, visando reconstituir sua moral, embora nem todas as medidas tomadas tenham sido as mais recomendadas. Mais ainda, essa tro-

2 Vide o projeto "Historiografia Militar" disponível na HP da Academia Montese (www.geocities.com/academiamontese) 
pa foi objeto de escárnio por parte dos pracinhas mais experientes (os do $6 .^{\circ}$ $\mathrm{RI}$, os primeiros a chegar ao front $\mathrm{e}$, portanto, os mais adaptados ao ambiente de luta), que apelidaram o $1 . \% 11 .{ }^{\circ} \mathrm{RI}$ de "Laurindos", numa alusão a um conhecido samba da época cujo refrão era "Laurindo desce o morro".

O extraordinário é que esse batalhão foi colocado em primeiro escalão no ataque à cidade de Montese em 14 de abril de 1945, sofrendo as piores baixas, mas logrando atingir o objetivo de capturar a cidade, naquele que foi o único caso de cumprimento das missões atribuídas pelo comando do V Exército norte-americano naquele terrível primeiro dia da Ofensiva da Primavera de 1945. Essa transformação radical na motivação para o combate de uma mesma tropa é que requer uma explicação, a qual, acredito, só pode ser buscada no entendimento do processo de formação de identidades de grupo e nos sentimentos dos pracinhas diante da guerra naquele estágio. É claro que ainda estamos longe de compreender todas a implicações desse processo, dado que a pesquisa ainda está em fase preliminar.

$\mathrm{O}$ que interessa nesse processo é saber como grupos heterogêneos e com moral baixa para o combate, sem acreditar na capacidade de enfrentar seus inimigos, puderam afinal ter se convertido em combatentes determinados e eficientes, o que exige mais alguns comentários sobre o contexto histórico da fase mais positiva da FEB.

Com a chegada do mês de abril de 1945, finalmente os exércitos aliados na Itália estavam prontos para desencadear a Ofensiva da Primavera contra os alemães, tida como um esforço final para acabar com a guerra naquele teatro de operações. Segundo os planos, a ofensiva deveria redundar na captura da cidade de Bolonha e no início da destruição final das tropas alemãs na Itália. Era intenção do comando aliado avançar até o vale do Rio Pó e tomar os seus locais de travessia antes que os alemães tivessem tempo de recuar para além dele e estabelecer uma nova frente defensiva - como sempre fizeram em três diferentes ocasiões - na Campanha da Itália. Cabia à FEB apoiar o ataque principal a ser desfechado pela 10. ${ }^{a}$ Divisão de Montanha (a elite do exército norte-americano), tomando a cidade de Montese.

Programada originalmente para ser mera "diversão" secundária ao ataque principal da $10 .^{\mathrm{a}} \mathrm{DM}$, o assalto brasileiro a Montese acabou por assumir uma importância totalmente desproporcional ao seu tamanho. É cogitado até mesmo que os nazistas tenham confundido o ataque da FEB com o assalto principal da Ofensiva de Primavera do V Exército, identificando os poucos tanques americanos que acompanhavam nossa infantaria 
como sendo a vanguarda da $1 .{ }^{a}$ Divisão Blindada Americana, que, na verdade, estava em outro setor. $\mathrm{O}$ fato de terem repelido o ataque principal levado a cabo pela $10 .{ }^{a} \mathrm{DM}$ com relativa facilidade e infligido pesadas perdas aos norte-americanos (553 baixas apenas no primeiro dia de ataque em troca de ganhos insignificantes de terreno) deve ter contrastado fortemente com a rapidez e a determinação do avanço brasileiro para Montese. Os alemães reagiram violentamente ao ataque dos pracinhas, destinando à área da FEB - por exemplo - mais granadas de artilharia do que todas as outras tropas sob comando norte-americano. De fato, segundo registros da inteligência militar do V Exército, dos 2.800 tiros de artilharia disparados pelos nazistas contra todo o $\mathrm{V}$ Exército, couberam às tropas brasileiras nada menos de 1.800. A artilharia da FEB respondeu à altura, replicando com outros 9.600 disparos.

Dessa forma, a FEB não apenas garantiu com o seu sacrifício a cobertura do flanco exposto da divisão que formava a vanguarda no ataque como, ainda por cima, atraiu para si o grosso do fogo inimigo, auxiliando talvez decisivamente o ataque principal, que, àquela altura, enfrentava grandes dificuldades. Aliás, ao fim do primeiro dia da ofensiva, metade das tropas atacantes da $10 .{ }^{\mathrm{a}} \mathrm{DM}$ recebeu ordens de cessar o ataque, tamanha a desproporção entre as cruéis perdas sofridas e os magros ganhos acumulados. Os brasileiros, por seu turno, perseveraram na conquista dos morros adjacentes a Montese, a despeito das enormes baixas, só interrompendo seu ataque quando o inimigo já iniciava sua retirada para o norte, acossado pela penetração - afinal bem sucedida - da $10 .^{a} \mathrm{DM}$.

$\mathrm{O}$ aspecto da Batalha de Montese que mais chama atenção diz respeito ao elevado grau de motivação para o combate do soldado brasileiro. Naturalmente que era do interesse do comando instigar ao máximo o espírito de luta de suas tropas, bem como garantir as condições materiais para o êxito das operações. As providências nesse sentido são assim descritas pelo chefe do Estado-Maior da FEB e por um simples combatente:

Desde 20 de março, data da Conferência no QG do IV Corpo, já se sabia que, dali em diante, começava-se a viver para a ofensiva final. Essa era a palavra do alto comando do V Exército. Chegara até nós e despertava, com o pensamento na vitória, a esperança no horizonte, no regresso à Pátria. Queríamos deixar uma impressão duradoura. E os preparativos 
passaram a ser intensos, não somente no recompletamento das unidades, como no seu reaparelhamento, revisão dos transportes motorizados, manutenção em larga escala. Também não foi esquecido o lado moral e psicológico. Tôda a tropa passou a se orgulhar das proezas de Monte Castelo, Soprassasso, Castelnuovo. Os raides de patrulhas eram exaltados. (BRAYNER, 1968, p. 395)

Na passagem de 13 para 14 de abril, ninguém dormiu nem repousou naquelas montanhas ocupadas por brasileiros, embora estranhamente, a artilharia alemã se fizesse omissa. Os canhões haviam silenciado e a paz baixara sobre o front. Era apenas a calmaria que antecede a tempestade. Mas também ninguém estava preocupado em se resguardar nos abrigos; todos movimentavam-se nos preparativos das armas e bagagens aliviadas. Outros andavam de posição em posição, cumprimentando os conhecidos, despedindo-se dos amigos. Nunca se vira tanta gente animada em se lançar à fogueira:

- Voce vai atacar com quem? .....

Uma coisa, contudo, animava os jovens brasileiros que sustentavam em suas mãos as armas de guerra: sentiam-se mais uma vez como peças de um esquema de combate bem planejado. O apoio logístico fazia-se presente. (SOARES, 1985, p. 307)

As transcrições acima foram tiradas das memórias de dois indivíduos que, com razão, podem ser considerados representantes dos extremos da escala hierárquica militar. Suas palavras falam por si. A primeira é do coronel comandante do Estado Maior da FEB. A segunda de um modesto sargento. Em ambas, revela-se o orgulho e a confiança de indivíduos que se sentem capazes de executar suas missões, desafiando mesmo os perigos que se aproximam. Notamos também a preocupação com a imagem que seria legada à História Militar pela única tropa terrestre a representar o Brasil na Segunda Guerra Mundial (justamente a FEB). Não deixa de ser uma ironia o fato de que uma tropa composta pelos elementos que, pela sua origem social e étnica, sempre foram desprezados pela elite dirigente da nação e do próprio exército tenha chegado a forjar tamanha capacidade de luta - e isso para eterna glória histórica daquela mesma nação e deste mesmo exército.

Para além desses depoimentos sobre o momento que antecede o combate, devemos levar em conta também informações sobre a batalha pro- 
priamente dita. Há evidências a respeito da moral dos combatentes da FEB que se relacionam tanto com o combate propriamente dito (em que houve 426 baixas entre mortos, feridos, mutilados e desaparecidos, quase a soma dos quatro ataques ao Monte Castelo entre novembro de 1944 e fevereiro de 1945) quanto à fase que o antecedeu. Numa palavra, são manifestações de uma tropa com uma moral elevada e de grande espírito combativo.

Essa confiança na capacidade de superar os desafios e perigos do campo de batalha parece ter se solidificado a partir da tomada do Monte Castelo (21 de fevereiro 1945). De fato, a superação dos traumas decorrentes de quatro tentativas fracassadas de tomar aquela posição aos alemães só poderia mesmo se dar com a queda final do morro em mãos brasileiras. Os depoimentos disponíveis, colhidos de representantes de diversos níveis hierárquicos, dão conta da depressão que ia sendo acometida à FEB à medida que iam se sucedendo os fracassos em relação ao Monte Castelo. Na penúltima tentativa, a moral estava decididamente ruim, como atesta o volume de casos psiquiátricos e outras baixas que a tropa sofreu no período. A partir de 21 de fevereiro, isso tudo começa a mudar. Aliás, é comum encontrar referência ao fato de que a tomada do Monte Castelo era um imperativo de ordem moral, questão de honra etc. para a FEB.

Para além do tônico moral que representou a tomada de Monte Castelo, devemos levar em conta que o prolongado (média de 3 meses) período de adaptação do soldado ao front estava finalmente completo em fevereiro de 1945. Aqueles que não foram vítimas de traumas e outros distúrbios finalmente haviam aprendido a levar a vida na linha de frente, tinham formado e se integrado a grupos de combatentes, cujos líderes agora também tinham experiência de combate. Numa palavra, a FEB agora era composta de veteranos. A atitude mental do veterano em relação às dificuldades da guerra só pode ser descrita como de adaptação perfeita ou quase isso, como se observa nos exemplos abaixo.

Dois pracinhas acabaram topando com uma casamata alemã e logo resolveram ocupá-la. Mas um cheiro dos diabos vinha lá de dentro. Quando entramos, um espetáculo hediondo se nos deparou: quatro alemães semicarbonizados sentados em tomo de uma mesa. Um deles ainda segurando três cartas na mão direita. Haviam sido surpreendidos pelos americanos e uma descarga de lança-chamas fizera todo aquele estrago. Mas o 
Ferreira não desistiria de morar ali confortavelmente. Os outros que se enterrassem na terra. - Vamos, pessoal! Vamos jogar esses caras aí pra fora e ocupar isto aqui. Tá bom demais pra gente trocar por um buraco no chão... Quanto a mim, rejeitei a idéia prontamente. Mas uns três ou quatro pracinhas toparam. Depois de enterrarem os cadáveres carbonizados, instalaramse na casamata. Esse era, nesta altura dos acontecimentos, o espírito do combatente. (PISKE, 1984, p. 165)

Tolice do Randi, pedir voluntários. "Dá azar", alegavam. Cumpriam qualquer missão, sem pestanejar, desde que recebessem ordens. Eram agora veteranos! Soldados rijos, endurecidos na luta. Tão bons quanto os melhores. Sofridos pracinhas de infantaria. Orgulhavam-se disso! Aprenderam, a duras penas, os segredos da guerra nas montanhas nevadas que os manuais não ensinaram. Habituaram-se à rotina do front: quarto de sentinela e patrulhas. Durante o dia, reconheciam o vale. Noite adentro aventuravam-se além, patrulhando o monte S. Filomena, a cota 1118, as casas di Ercole, di Sotto e di Sopra. Faziam, sem um queixume, o bruto quarto de sentinela, nas madrugadas glaciais e silenciosas. Missão capaz de assustar o mais valente. Já não temiam, como nos primeiros dias, o traiçoeiro 88. Agora, quando a primeira granada passava, riscando o ar, corriam para os sólidos abrigos que êles mesmos construíram. Ali permaneciam tranqüilos, aguardando que o bombardeio cessasse. (RODRIGUES, 1969, p. 186)

Para além da adaptação bem sucedida, é de notar o orgulho profissional, derivado dos feitos militares de destaque que eram divulgados ou circulavam entre os soldados. A exaltação das proezas das patrulhas, como se refere Lima Brayner, tinha precisamente esse objetivo: fazer com que o combatente se orgulhasse dos feitos de seus camaradas e com eles se identificasse, buscando igualar seu desempenho, o que é pré-condição de aceitação de si pelo seu próprio grupo. É bem conhecida a afirmação de que os soldados comuns não aspiram a serem heróis, uma vez que não desejam correr riscos excepcionais. Contudo, nenhum deles gostaria de ser considerado como o menos bravo de seus pares, justamente por temer não mais ser aceito ou vir a não conseguir se integrar ao seu grupo, de cujo pertencimento depende tudo o mais (a vida, a segurança, a felicidade etc.) em tempo de guerra. 


\section{Conclusão}

O objetivo deste artigo sempre foi, menos do que avançar algumas conclusões provisórias sobre o estado da arte no que se refere ao estudo das motivações para o combate e a busca do êxito militar, colocar como problema histórico o entendimento da nossa experiência de combate na Campanha da Itália. Partimos do pressuposto de que a literatura que busca uma resposta para nosso relativo êxito naquela luta é inconsistente com as evidências históricas disponíveis. A produção e a memória oficial têm características ufanistas e fortes comprometimentos institucionais. Elas exaltam a garra e a coragem dos combatentes brasileiros (MASCARENHAS, 1947; COSTA, 1980; etc.) e as consideram como responsáveis pela superação de quase todas as nossas dificuldades. Há também autores que buscam, no apoio logístico e político norte-americano, bem como nas insuficiências de todo tipo de que padeciam as forças armadas alemãs no final do conflito, a explicação para nossos sucessos (WAACK, 1995). De ponto de vista do estágio atual que vimos desenvolvendo na pesquisa sobre a FEB, assumimos que nem uma nem outra corrente nos fornece uma explicação consistente sobre o processo de conversão da FEB de um enigma militar em uma força de combatentes motivados e eficientes. Mesmo um autor crítico da FEB como Waack (1995) reconhece que Montese era extraordinariamente bem defendida e que, pelo menos até o suicídio de Hitler (28 de abril de 1945), não se verificaram sinais de quebra de moral ou perda de coesão por parte das tropas alemãs que lutavam na Itália. Somente a partir da divulgação da morte do Fuehrer é que começaram as rendições em massa. Mesmo assim, a captura de toda a 148. ${ }^{a}$ Divisão de Infantaria alemã $(15.000$ combatentes) pela FEB em Fornovo - precisamente naquela data - exigiu consideráveis esforços militares por parte dos brasileiros, embora a literatura militar norte-americana não dê ao episódio mais relevo do que a descrição da captura de um simples regimento (5.000 homens) por parte de suas próprias tropas ao se referir aos episódios de abril de 1945 (STARR, 1947).

Independentemente dessas controvérsias historiográficas, as quais demandariam o espaço de um outro artigo para serem adequadamente discutidas, acredito que o entendimento dos processos históricos afetos à formação de identidades coletivas e sentimento de grupo é da mais alta relevância para o avanço do conhecimento em nossa disciplina. E, no que se 
refere a esses processos, temos que reconhecer que ainda estamos longe de compreender na sua inteireza a importância do estudo da única experiência de combate prolongada e intensa pela qual passaram nossas forças armadas no século XX: justamente a Campanha da FEB na Itália.

Defendemos a necessidade e urgência desses estudos por entender que o comportamento agressivo não pode ser tomado como um dado $a$ priori da realidade, mas, muito pelo contrário, uma atitude socialmente produzida, isto é, um problema prático e concreto que vem sendo encarado de forma cotidiana por virtualmente todos os grupos dedicados à organização da agressão aos nossos semelhantes. Os pressupostos e implicações do processo da construção social de comportamentos agressivos regulados por instituições militares, visando lograr eficácia no campo de batalha, é, pois, objeto digno de ser alçado ao primeiro plano nas preocupações daqueles interessados em interpretar os nexos entre cultura e poder nas sociedades contemporâneas.

\section{Referências}

ARRUDA, D. C. de. Impressões de um infante sobre o comando. In: ARRUDA, D. C. et al. Depoimentos de oficiais da reserva sobre a FEB. 3. ed. Rio de Janeiro: Cobraci Publicações, 1950. p. 70.

BONALUME, R. A nossa Segunda Guerra Mundial: os brasileiros em combate. Rio de Janeiro: Expressão e cultura, 1995.

BRAYNER, F. de L. A verdade sobre a FEB - memórias de um chefe de estado maior na campanha da Itália. Rio de Janeiro: Civilização Brasileira, 1968.

Recordando os bravos. Rio de Janeiro: Civilização Brasileira, 1977.

CAPELATO, M. H. Os arautos do liberalismo. São Paulo: Brasiliense, 1989.

Multidões em cena. São Paulo: Brasiliense, 1994.

CARNEIRO, M. L. T. O anti-semitismo na era Vargas. São Paulo: Brasiliense, 1995.

CASTELO BRANCO, M. T. O Brasil na II Grande Guerra. Rio de Janeiro: Biblioteca do Exército Editora, 1960. 
CYTRYNOWICZ, R. Guerra sem guerra: a mobilização e o cotidiano de São Paulo durante a Segunda Guerra Mundial. São Paulo: Edusp, 2000.

DURBIN, E. F. M.; BOWLBY, J. Personal aggressiveness and war. In: GAMSON, W. ; MODIGLIANI, A. (Orgs.). Conceptions of social life: a text reader for social psychology. Boston: Little, Brown and Company, 1974. p. 557-567.

FERRAZ, F. C. A. História militar e memórias. Inédito.

GAMSON, W.; MODIGLIANI, A. (Orgs.). Conceptions of social life: a text reader for social psychology. Boston: Little, Brown and Company, 1974.

GOLD, M. A new outline of social psychology. Washington: American Psychological Association, 1997.

HOLMES, R. Firing line. London: Pimlico, 1985.

LEIBING, A.; BENNINGHOFF-LUHL, S. (Orgs.). Devorando o tempo: Brasil, o país sem memória. São Paulo: Mandarim, 2001.

LORIGA, S. A experiência militar. In: LEVI, G.; SCHMITT, J. C. (Org.). História dos jovens: a época contemporânea. São Paulo: Cia. das Letras, 1999. p. 17-47.

MANNA, R. de L. Alguns aspectos da psiquiatria militar. Curitiba, 1950. Tese (Livre-Docência) - Faculdade de Medicina da Universidade Federal do Paraná.

MARSHALL, S. L. A. Men against fire. Nova York: William Morrow \& Co., 1947.

MAXIMIANO, C. C. Onde estão nossos heróis: uma breve história dos brasileiros na 2." Grande Guerra. São Paulo: Maximiano, 1995.

MAXIMIANO, C. C.; OLIVEIRA, D. de. Raça e Forças Armadas: o caso da campanha da Itália (1944-45). Revista Estudos de História, São Paulo, v. 8, n. 1, p. 157-184, 2001.

MORAES, J. B. M. de. A FEB pelo seu comandante. 2. ed. Rio de Janeiro: Gal. G. C. de Farias, 1960.

MORRIS, E. Circles of hell: the war in Italy (1943/45). New York: Crow Publishers, 1993.

NOSSO SÉCULO. São Paulo: Abril, v. 8, 1984.

O, CONNEL, R. História da guerra: armas e homens. Lisboa: Teorema Ltda., 1990.

PILISUK, M.; HAYDEN, T. Is there a military-industrial complex which prevents peace? Consensus and counter vailing power in pluralistic systems. In: GAMSON, W.; MODIGLIANI, A. (Orgs.). Conceptions of social life: a text reader for social psychology. Boston: Little, Brown and Company, 1974. p. 580-591. 
PINHEIRO, J. J. B. Castelnuovo no conartigoda FEB. [S. 1.: s. n.], 1975. Escrito em 1972.

SARLO, B. (Org.) Paisagens imaginárias: intelectuais, arte e meios de comunicação. São Paulo: Edusp. 1997.

SEYFERTH, G. Construindo a nação: hierarquias raciais e o papel do racismo na política de imigração e colonização. In: MAIO, M.; SANTOS, R. (Orgs.). Raça, ciência e sociedade. Rio de Janeiro: Fiocruz/Centro Cultural do Banco do Brasil, 1996. p. $41-58$.

. Os paradoxos da miscigenação: observações sobre o tema imigração e raça no Brasil. Estudos afro-asiáticos, n. 20, p. 165-184, 1991.

SILVEIRA, J. X. da. Cruzes brancas: diário de um pracinha. Rio de Janeiro: J. Alvaro, 1963. p. 38-39.

WAACK. W. As duas faces da glória. Rio de Janeiro: Nova Fronteira, 1985.

WINTER, J.; SIVAN, E. (Orgs.). War and remembrance in the twentieth century. London: Cambridge University Press, 1999.

WINTER, J. Forms of kinship and remembrance in the aftermath of the great war. In: WINTER, J.; SIVAN, E. (Orgs.). War and remembrance in the twentieth century. London: Cambridge University Press, 1999. p. 40-60. 